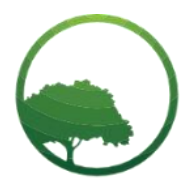

Research in Business \& Social Science

IJRBS VOL 10 NO 3 ISSN: 2147-4478

\title{
Service failure and complaints management in higher education institutions
}

Steven Kayambazinthu Msosa

Researcher, Department of Marketing, Mangosuthu University of Technology, 511 Mangosuthu Highway, Umlazi, KwaZulu-Natal, 4031, South Africa

A R T I C L E I N F O
Article history:
Received 02 March 2021
Received in rev. form 12 April 2021
Accepted 14 April 2021
Keywords:
Service failure; complaints
management; customer expectation;
higher education institutions.
JEL Classification:
E22

\section{A RTICLE INFO}

Article history:

Received in rev. form 12 April 2021

Accepted 14 April 2021

E22

\begin{abstract}
A B S T R A C T
The higher education sector has evolved over the past decade due to the ever-changing needs of students who are its primary customers. As a result, most students have to deal with unmet expectations which subsequently lead to service failure. Even though service failure cannot be eliminated, higher education institutions are expected to provide an effective complaints management system to resolve student problems and service failure incidents. This study analysed service failure and complaints management in higher education institutions. A quantitative, descriptive and cross-sectional study was undertaken using 430 full-time students across three public universities in South Africa. The findings of this study showed that students encounter various forms of service failures in institutions of higher learning with the majority experiencing service failures in respect of funding and academic registration. Also, most of the students were generally satisfied with the complaints management system. Thus, this study can help institutional managers to understand service failure incidents confronting the sector. Furthermore, the study provides an opportunity for institutional managers to assess the effectiveness of the complaints management system and make improvements to ensure a better student experience.
\end{abstract}

(C) 2021 by the authors. Licensee SSBFNET, Istanbul, Turkey. This article is an open access article distributed under the terms and conditions of the Creative Commons Attribution (CC BY) license (http://creativecommons.org/licenses/by/4.0/).

\section{Introduction}

Complaints handling is an integral part of the service recovery process and essential to addressing service failure. Chahal and Devi (2015) observe that few cases of service failures or complaints are reported and registered because people simply don't know where to complain and there is limited time to complain. In some cases, poor service encounters or being assisted by non-responsive service providers may lead to customers believing that registering complaints is an exercise in futility because nobody will attend to the complaint or they will simply be ignored. Customer complaints may arise because of a service or product that is defective, unfulfilled customer expectation or a broken promise. Therefore, a poorly executed service, unreliable service and failure to meet commitments may all lead to customer complaints (Chan et al., 2016). Sometimes, there is a wrong belief among service employees that low complaints represent good performance to the extent that they do not value complaints (Tan et al., 2014).

Service failures are context-specific and differ in frequency of occurrence. Besides, the reactions of customers concerning service failures are different from one organisation to another. In this regard, frontline employees play a crucial role in defining customer dissatisfaction (Khanmohammadi et al., 2014). Wilson et al., (2012) have noted that customers react differently to service failure. Emotions such as anger, discontent, disappointment, self-pity and anxiety can occur at any time. On the other hand, some scholars are of the view that service failures should not lead to panic. Customer complaints and service failure do not mean the end of the business but an opportunity to correct mistakes and improve customer satisfaction and relationship. Thus, it is only when service breakdown occurs that an organisation can evaluate its operations (Timm, 2011). Furthermore, customers who register complaints should not be viewed as charlatans or treated with contempt. Sometimes, service providers may take offence and be defensive when

* Corresponding author. ORCID ID: 0000-0001-9074-5644

(C) 2021 by the authors. Hosting by SSBFNET. Peer review under responsibility of Center for Strategic Studies in Business and Finance. https://doi.org/10.20525/ijrbs.v10i3.1098 
customers complain about their service offering. However, they need to view complaints as feedback and a tool for managing service failure incidents (Harris, 2013). Bateson and Hoffman (2016) believe that complainers are true customers because they inform the service providers that they have operational or managerial problems which need to be sorted out. Thus, service providers should be concerned about non-complainers because they have either left or are prepared to leave and defect to the competition.

The traditional method of addressing service or product failures is through the handling of complaints where aggrieved customers can make formal complaints regarding their experience. Complaints handling improves customer perception of the service orientation of the organisation even though it is inherently non-service oriented (Gronroos, 2007). Abbas et al, (2015) posit that service providers must provide every possible channel to enable customers to launch complaints on matters relating to service breakdown. This will enable the service provider to gain an understanding of the problems and engage the customer to redress any defects found. In doing so, the service provider will be able to retain the customer and minimise defections. Several studies have been conducted on complaints management in different sectors of the economy. Extant research shows evidence of literature on complaints management in hospitals (Bendall-Lyon \& Powers, 2001), banks (Bengül \& Y1lmaz, 2018), hospitality industry (Ramphal, 2016) and food processing industry (MacLeish, 2016). However, there is a dearth of research on complaints management in the higher education sector, specifically in South Africa. The South African higher education sector has not been immune to students' problems. For instance, students complain of food and housing problems (Dominguez-Whitehead, 2017), shortage of resources such as laptops and data, delays in funding and release of allowances, poor infrastructure and increased workload due to some staff operating from home (Ncokazi, 2020). Thus, failure to address these complaints and many others lead to students' dissatisfaction and in some cases protests (Tjønneland, 2017). It is against this background that there was a need to ascertain students' perception of service failure and complaints management. According to Price Waterhouse Coopers (2014), the momentum of change in higher education will continue to be robust and it is only institutions that respond appropriately to the present challenges that will be able to remain competitive, attractive and vibrant, while those that maintain the status quo will face challenges in meeting their goals. This study analysed service failure and complaints management system in higher education institutions with specific reference to South Africa. Specifically, the study analysed the following:

\section{i. Student perception of the causes of service failure \\ ii. Student perception of the nature of the service provided during the service failure \\ iii. Student perception of complaints management}

The following section provides a theoretical background on service failure and complaints management. Service failure and complaints management concepts are discussed. The research methodology that guided this study is provided, followed by results and a discussion of the findings. Lastly, this study provides a conclusion which encompasses recommendations and a suggestion for future research.

\section{Literature review}

\section{Conceptual Background}

\section{Service failure}

Michel (2001) notes that since services production and consumption cannot be separated, service performance and delivery can be attributed to several factors such as the behaviour of front-desk employees, the capacity of the system and the behaviour of customers that are part of the transaction. The perception of customers regarding the variation from the service norm or blueprint is viewed as service failure if it does not meet the customers' expectation of an ideal outcome or process. In some cases, customers treat incidents as service breakdown even when the process of the service rendered is in tandem with the service norm. Thus, the reported incident is treated as a service breakdown and leads to customer dissatisfaction. Extant research has categorised service failure in different ways. Failure categorisation is a very important aspect of failure analysis because it helps to identify types of frequent service failure incidents and provides insight into why these types of service failure incidents occur. It further provides information to minimise the occurrence of similar incidents in future (Gonzalez et al., 2005). Categorising or classifying service failures is very important for organisations. Previous research suggests that most firms fail to document service failures and this makes learning a challenge (Tax \& Brown, 1998).

According to Bitner et al., (1990), the classification of service failure incidents is based on three categories, viz. employee response to service delivery system failure, employee response to customer needs and requests and unprompted and unsolicited employee actions. On the other hand, Ishaque et al., (2016) believe that service failure consists of four major categories viz. employees' response to service delivery system, employees' response to implicit/explicit customer requests, unprompted and unsolicited employee' actions and problematic customer behaviour. Service delivery system failure represents product or service defects, slow/unavailable service, facility problem, unclear policy and when the food at the student cafeteria is not delivered acceptably. When lecturers fail to reschedule classes, due to timetable clashes or there are some seating problems for the students, the service failure is categorized as employee' responses to implicit and explicit customer requests. Another important category due to the employee' unprompted and unsolicited employee' actions involve employee' behaviour, wrong grades being given, lost examination results, and over-charging 
students fees on the statement. Lastly, sometimes service fails due to problematic student's behaviour or is more likely due to aberrant student' behaviour such as making noise and drunkenness.

\section{Complaints Management}

Complaints management is a process that is deemed as a key battleground where stakes are high and the outcome is not known. Thus, the complainant may leave the scene dissatisfied and less likely to return. On the other hand, if the service provider can address the problem to the satisfaction of the customer, the customer may leave the scene satisfied and will be likely to patronise the service or business in the future (Rust et al., 1992). Therefore, complaints handling should deal primarily with the outcome and secondly, the process. When the provision of speedy service recovery is not possible due to other matters such as lawsuits, the service provider must make sure that customers are updated on the issues surrounding their complaints (Stone, 2011).

Customer complaints provide the service provider with meaningful information which can prove useful in helping the firm to recognise their problems, recover from a service failure and maintain a sustainable relationship with customers. Therefore, laying out a clear complaints procedure will enable customers to know how to launch complaints, where to complain and this initiative should be favourably considered by service providers (Quy \& Lan, 2015). Besides, Service managers have no choice, but to learn about service failure incidents if service recovery is to be achieved. In this regard, customer complaints are essential and crucial feedback that helps managers to conduct a thorough analysis of the root cause of service failure and to detect areas within the operation that are leading to this (Lervik-Olsen et al., 2016). Therefore, service providers should create an environment or provide an experience that enhances customer perception of the likelihood of complaints being addressed satisfactorily or reaping some reward. Previous experience of the customer can be positive only if the service provider can do things right every time (Azam et al., 2013).

As part of continuous improvement, institutional managers need to communicate to students the various channels that can be used to voice their concerns or to register complaints (Hoffman and Lee, 2015). Students will derive satisfaction from a service recovery process if satisfied with the process of seeking the remedy. Furthermore, a fair complaint process that facilitates student flexibility and control is crucial to achieving student satisfaction. Universities are advised to come up with policies and a communication framework that is clear to students and which facilitates prompt and timely feedback to complainants (Waqas et al., 2014). Thus, service providers' complaints management system must be flexible to respond with speed in an event of service failure to ensure that the customer is not disadvantaged as a result of substandard service. The longer it takes to enforce service recovery, the higher the level of compensation needed (Ibrahim \& Abdallahamed, 2014). Service providers should establish good complaint management and service recovery system to avoid the spread of negative word-of-mouth accounts about the organisation and its products from disappointed or dissatisfied customers (Okyere \& Kumadey, 2015).

Customer complaints should be seen as both an opportunity and a problem. Complaints can create discomfort and fear. Conversely, organisations can view complaints as an opportunity to receive constructive customer feedback and to strive to use this to enhance their reputation, credibility, customer confidence and satisfaction (Scriabina \& Fomichov, 2007). This view is reinforced by GarinMunoz et al., (2016) who have noted that service providers should view complaints as opportunities since they provide the service provider with a second chance to make things right. One of the most important strategies is to encourage and track complaints. Service failure occurs when least expected and sometimes without the knowledge of the service provider such that it takes the customer to inform the service provider. Consequently, organisations can encourage and track complaints by developing a mindset that complaints are good, by making complaining easy, by being an active listener, by asking customers about specific issues and through conducting short surveys (Wilson et al., 2012).

\section{Research and Methodology}

This study followed a descriptive, quantitative and cross-sectional approach. Thus, in descriptive research, data is used to provide explanations regarding the characteristics of people and situations. Furthermore, descriptive studies play an important role in explaining the attributes of a given scenario such as market segments and factors influencing customer behaviour (Sekaran \& Bougie, 2016). A total of 430 students were used in this study. Judgemental sampling which is a non-probability sampling technique was used to ascertain students' perception based on their service failure experience using a self-administered questionnaire. The proponents of purposive sampling believe that, by focussing on respondents or traits that are considered helpful, the researcher can pick only those that can articulate views relevant to the study (Churchill et al., 2010). Besides, the choice of the sampling method was made because there is no sampling frame that allows the researcher to work only with students who have experienced service failure (Leow, 2015).

\section{Data and analysis}

A self-administered questionnaire was used to collect data. The respondents were met at their respective universities and a hard copy of the questionnaire was presented to them. A consent form requesting their approval to participate in the study was given to the students and it was also pointed out to them that their participation is voluntary such that they can withdraw from the study at any point without providing reasons. For the current study, data were analysed using descriptive statistics. Data analysis for descriptive statistics was computed using the Statistical Package for the Social Sciences (SPSS) 24.0. Tables were drawn to present information 
using frequency percentages. The descriptive statistics provided information relating to the demographic background of participants, causes of services failure, the nature of service provided during the service failure and complaints management. A Likert scale was used to gauge student feelings on complaints management with the designs ranging from $1=$ Strongly Disagree, $2=$ Disagree, $3=$ Uncertain, 4 = Agree and 5 = Strongly Agree. However, for the purpose of analysis, the scales were collapsed into three viz. Disagree, Uncertain and Agree.

Ethical clearance and permission to conduct the study were obtained from the three public universities. The final survey earmarked a sample of 460 students across the three public universities. However, a total of 430 usable questionnaires were received by the researcher. This represents a response rate of 93.5 percent which is considered very high.

\section{Results}

\section{Demographic information}

The findings of this study show that the majority of respondents were South Africans (98.6 percent) followed by other nationalities (1.4 percent). The gender participation comprised of 44.7 percent females and 55.3 percent males. In terms of the race composition, the majority of the respondents were Africans ( 95.6 percent) followed by Indians ( 2.8 percent) and Whites ( 1.6 percent). In terms of students' participation, the sample respondents from the three universities were 30 percent, 49.8 percent and 20.2 percent respectively.

\section{Students perception of the causes of service failure}

As indicated in Table 1, the majority of respondents had experienced service delivery system failure (42.1 percent) followed by unfulfilled needs and requests (24.2 percent), unprompted and unsolicited action (23.7 percent), while service failure as a result of problematic customers (students) amounted to 10 percent. Table 1 shows the categories of the causes of service failure.

Table 1: Categories of the causes of service failure

\begin{tabular}{llll}
\hline Categories of the causes of service failure & Frequency & Percent & $\begin{array}{l}\text { Cumulative } \\
\text { Percent }\end{array}$ \\
\hline Service delivery system failure & 181 & 42.1 & 42.1 \\
\hline Unfulfilled needs and requests & 104 & 24.2 & 66.3 \\
\hline Unprompted and unsolicited action & 102 & 23.7 & 90.0 \\
\hline Problematic customers (students) & 43 & 10.0 & 100.0 \\
\hline Total & 430 & 100.0 & \\
\hline
\end{tabular}

\section{Nature of services provided during service failure}

The results as depicted in Table 2 reveal that the majority of students experience service failures in respect of funding ( 24.9 percent) followed by service failure during the registration process ( 24.2 percent), service failure in respect of accommodation or student housing (17.7 percent), administrative service failure (14.7 percent), service failure in the classroom ( 7.2 percent), service failure in respect of student cafeteria (5.1 percent), service failure in respect of the library (4.7 percent) while other service failures amounted to 1.6 percent. Table 2 shows the breakdown of the nature of services provided in the higher education institutions where students can experience service failure.

Table 2: Nature of the service failure for the services provided at universities

\begin{tabular}{llll}
\hline Nature of service failure & Frequency & Percent & $\begin{array}{l}\text { Cumulative } \\
\text { Percent }\end{array}$ \\
\hline Service failure during the registration process & 104 & 24.2 & 24.2 \\
\hline Service failure in respect of funding & 107 & 24.9 & 49.1 \\
\hline Administrative service failure & 63 & 14.7 & 63.7 \\
\hline Service failure in the classroom & 31 & 7.2 & 70.9 \\
\hline Service failure in respect of the library & 20 & 4.7 & 75.6 \\
\hline Service failure in respect of accommodation & 76 & 17.7 & 93.3 \\
\hline Service failure in respect of student cafeteria & 22 & 5.1 & 98.4 \\
\hline other & 7 & 1.6 & 100.0 \\
\hline Total & 430 & 100.0 & \\
\hline
\end{tabular}




\section{Students perception of the complaints management system}

This section provides a discussion of findings relating to students' perception of complaints management in their designated universities. Students were requested to ascertain whether the university or employees encourage them to complain when they face problems. As shown in Table 3, 23.9 percent (103) of the respondents disagree while 29.1 percent (125) were uncertain. The majority of respondents (47 percent; $n=202$ ) agree that the university and its employees encourage students to complain. With respect to whether the university provides different platforms for registering complaints, the results show that 21.4 percent (92) of the respondents disagree while 33 percent (142) of the respondents were uncertain. Furthermore, 45.6 percent (196) (which represents the majority of respondents) agree that the university has different platforms or communication channels for registering complaints. Further to the above-highlighted statements, students were asked whether the university publicise where to register complaints. The results reveal that 38.8 percent (167) representing the majority of respondents disagree, followed by 33 percent (142) of the respondents who agree and 28.1 percent (121) who were uncertain as to whether or not they knew where to register a complaint because the university has publicised.

In order to gain a deeper understanding of the complaints management system in universities, students were also asked whether it was easy, fast and convenient to register a complaint. The findings show that the majority of the respondents $(41.2$ percent; $\mathrm{n}=177)$ disagree while 27.9 percent (120) were uncertain. Thus, 30.9 percent (133) of the respondents agree that it was easy and fast to register complaints at their institution of higher learning. With respect to whether there was an authority to settle complaints by members of staff, the results show that 30.5 percent (131) of the respondents disagree that members of staff had the authority to settle complaints while 32.3 percent (139) of the respondents were uncertain. The findings further show that the majority of the respondents (37.2 percent; $n=160$ ) agree that members of staff had the authority to settle or address complaints registered at the university.

Table 3: Frequency distribution of complaints management

\begin{tabular}{|c|c|c|c|c|c|c|c|c|}
\hline \multirow[t]{2}{*}{ Complaints Management } & \multicolumn{2}{|c|}{ Disagree } & \multicolumn{2}{|c|}{ Uncertain } & \multicolumn{2}{|c|}{ Agree } & \multicolumn{2}{|c|}{ Total } \\
\hline & $\mathrm{n}$ & $\%$ & $\mathrm{n}$ & $\%$ & $\mathrm{n}$ & $\%$ & $\mathrm{n}$ & $\%$ \\
\hline Encourage complaints & 103 & $23.9 \%$ & 125 & $29.1 \%$ & 202 & $47 \%$ & 430 & $100 \%$ \\
\hline Platforms for complaints & 92 & $21.4 \%$ & 142 & $33 \%$ & 196 & $45.6 \%$ & 430 & $100 \%$ \\
\hline Knew where to complain & 167 & $38.8 \%$ & 121 & $28.1 \%$ & 142 & $33 \%$ & 430 & $100 \%$ \\
\hline Easy to register complaints & 177 & $41.2 \%$ & 120 & $27.9 \%$ & 133 & $30.9 \%$ & 430 & $100 \%$ \\
\hline Authority to settle complaints & 131 & $30.5 \%$ & 139 & $32.3 \%$ & 160 & $37.2 \%$ & 430 & $100 \%$ \\
\hline
\end{tabular}

\section{Discussion}

This study assessed students' perception of service failure and complaints management in higher education institutions. A descriptive analysis of demographic information, causes of service failure, the nature of service failure experienced by students and the complaints management system utilised in higher education institution was performed. The findings of this study show that the majority of students' encounter service delivery system failure and the least experienced service failure is caused by other students known as problematic students. Previous research suggests that customers are normally upset when other customers do not adhere to service processes or norms. Moreover, the dissatisfaction of customers who adhere to procedures escalates when front-desk employees do not respond appropriately because in any organisation there are explicitly or implicitly established service norms that customers should abide by (Gursoy et al., 2017). Thus, a better service experience can be achieved if customers or students are oriented on avoiding problematic or uncivil students who can affect their perception of the service provider and service rendered (Torres et al., 2017).

A further analysis was conducted regarding the nature of service failure experienced by students. The results reveal that the majority of students' experience service failure in respect of funding and the least problem experienced by students is in respect of other service failures. According to Clarke (2015), students who have registered through the South African tertiary education funding scheme known as NASFAS are sometimes informed that their names are not reflecting in the system such that this makes it difficult for them to access tuition fees and meal allowances. In order to ascertain the perception of the complaints management system used in higher education institutions, students were asked whether the university or its employees encourage complaints. The findings reveal that the majority of the students agree that universities encourage them to complain when they have problems. Merlo et al., (2018) argue that one of the powerful strategies is for firms to encourage customers to register complaints. Thus, this will enable the firm to understand customer needs and find ways of addressing them. Similarly, Soares et al., (2017) observe that organisations should encourage customers to provide feedback when they are not happy with the service rendered. Encouraging dissatisfied customers to give feedback is important. Rather than treating customers as annoyances, service managers should view complaints as a tool for gaining customer trust. In sectors where there is cut-throat competition, an organisation should work hard to retain current 
customers and transform dissatisfied customers into brand ambassadors. Thus, to build customer trust, an organisation must take deliberate initiatives to champion the welfare of customers by rectifying errors. In particular, service-oriented organisations should provide incentives as one way of encouraging customers to provide feedback on any service failure.

Students were also requested to evaluate if the university provides different platforms for registering complaints. The findings show that the majority of the students agree that the university provides them with different platforms for registering complaints. According to Villi and Koc (2018), higher education institutions need to set up appropriate complaint systems as one way of encouraging students to express their dissatisfaction easily. Brief customer satisfaction surveys in various forms may be administered to collect information and to monitor student satisfaction levels continuously. In addition, mobile phone applications, SMS and web-based portals can be used to assist students to register complaints (Badhe et al., 2017). Additional analysis was conducted to ascertain whether the university publicises where to register complaints. The results show that the majority of students disagree that the university publicises where to register complaints. Kloviene and Pazeraite (2017) believe that feedback from the students is beneficial and this is the reason why universities should make it clear or publicise to their students that any type of feedback is encouraged. Thus, organisations should strive to do the right things from the beginning. Even though things may not always go according to the service blueprint, a good complaint management system can help to restore customer satisfaction and lead to a sustainable relationship.

Students were further requested to evaluate whether it is easy, fast and convenient to register a complaint. The majority of the students disagree that it is easy, fast and convenient to register a complaint. Kloviene and Pazeraite (2017) add that higher education institutions should make sure that the complaint management procedures should be easy to understand by both students and the employees of the institution. Dissatisfied students should clearly understand how to file the complaint and employees need to know who is to accept those complaints. Lastly, this study sought to evaluate student perception of whether university employees had the authority to address complaints. The results show that the majority of the students agree that the employees had the authority to address their complaints. According to Chan et al., (2017), service encounter quality is determined by employees who are empowered and are familiar with the complaint's management blueprint. Therefore, management should ensure that training focussing on resolving customer complaints and service recovery is provided. In addition, cases registered by the organisation should be reviewed on regular basis as one way of fostering continuous improvement.

\section{Conclusions}

Service failures are a common phenomenon in the service sector, specifically in higher education institutions. However, an effective complaints management system can be useful in addressing the challenges students are facing or whenever they are confronted with a service failure scenario. This study aimed to analyse student perception of service failure and customer complaints management system in the South African higher education sector. The various service failure incidents that students encounter in higher education institutions range from student funding, registration, administrative failure, classroom, library, accommodation and student cafeteria among others. The findings of this study showed that service delivery system failure and service failure in respect of funding accounted for the majority of the service failures. Thus, the management of higher education institutions is advised to pay particular attention to the aforementioned service failure incidents and create an enabling environment where student problems can be registered and resolved efficiently.

Based on the findings of this study, the management of higher education institutions is encouraged to facilitate the training of customer-facing employees so that they gain new skills on how to deal with student problems. Furthermore, there is a need for institutional managers to provide a good complaints management system that encourages students' complaints. Furthermore, institutions should avail several platforms for registering complaints and give authority to members of staff to resolve students' complaints. There is nothing so frustrating for students than having to deal with a clueless academic staff or employee who does not have the authority to address their problems. This study has contributed to the literature on service failure and complaints management in the higher education sector. Future research should focus on how institutions can address the reported service failure incidents.

\section{References}

Abbas, M.R., Abdullateef, A.O. \& Mokhtar, S.S.M. (2015). Does service recovery lead to customer satisfaction and loyalty in the airline industry? A perceived justice theory approach. World Applied Sciences Journal, 33(2), 256-262.

Azam, K., Javed, M., Arif, S., Rukhsar, N., Muzaffar, S., Ayyaz., Nawaz, M.A \& Ali, M.A.(2013). Determinants affecting customer's complaint intention A study in the context of Pakistan`s retail market. International Journal of Learning \& Development, 3(6), 139-52.

Badhe, T., Birajdar, M. \& Mapari, S. (2017). Mobile Application for GrievanceRegistration. Imperial Journal of Interdisciplinary Research, 3(5), 954-958.

Bateson, J.E.G \& Hoffman, K.D. (2016). Services Marketing: Concepts, Strategies and Cases. 5th ed. Texas: South-Western Cengage Learning.

Bendall-Lyon, D., \& Powers, T. L. (2001). The role of complaint management in the service recovery process. The Joint Commission journal on quality improvement, 27(5), 278- 286. 
Bengül, S. S., \& Y1lmaz, C. (2018). Effects of customer complaint management quality on business performance in service businesses: An application in turkish banking sector. Boğaziçi Journal, 32(2), 77-100.

Bitner, M.J., Booms, B.H. \& Tetreault, M.S. (1990). The service encounter: Diagnosing favourable and unfavourable incidents. Journal of Marketing, 54, 71-84.

Chahal, H. \& Devi, P. (2015). Consumer attitude towards service failure and recovery in higher education. Quality Assurance in Education, 23(1), 67-85.

Chan, G.S.H., Hsiao, A.C.H. \& Lee, A.L.Y. (2016). Exploration of customer complaint behaviour toward Asian full-service restaurants. International Journal of Marketing Studies, 8(2), 46.

Chan, G.S.H., Tang, I.L.F. \& Sou, A.H.K. (2017). An Exploration of Consumer Complaint Behaviour towards the Hotel Industry: Case Study in Macao. International Journal of Marketing Studies, 9(5), 56.

Churchill, G.A., Brown, T.J. \& Suter, T.A. (2010). Basic marketing research. 7th ed. Mason, Ohio: South-Western Cengage Learning

Clarke, S. (2015). Students struggle to access NSFAS funds. Available online:https://www.pa.org.za/blog/students-struggle-accessnsfas-funds. Accessed 19/03/2021.

Dominguez-Whitehead, Y. (2017). Food and housing challenges:(Re) framing exclusion in higher education. Journal of Education (University of KwaZulu-Natal), (68), 149-169.

Garin-Muñoz, T., Pérez-Amaral, T., Gijón, C. \& López, R. (2016). Consumer complaintbehaviour in telecommunications: The case of mobile phone users in Spain. Telecommunications Policy, 40(8), 804-820.

Gonzalez, G.R., Hoffman, K.D. \& Ingram, T.N. (2005). Improving relationship selling through failure analysis and recovery efforts: A framework and call to action. Journal of Personal Selling \& Sales Management, 25(1), 57-65.

Gronroos, C. (2007). Service management and marketing: Customer management in service competition. $3^{\text {rd }}$ ed. West Sussex: John Wiley \& Sons Ltd.

Gursoy, D., Cai, R. \& Anaya, G.J. (2017). Developing a typology of disruptive customer behaviors: Influence of customer misbehavior on service experience of by standing customers. International. Journal of Contemporary Hospitality Management, 29(9), 2341-2360.

Harris, E.K. (2013). Customer service: A practical skills approach. 6th ed. New Jersey: Pearson.

Hoffman, K.D. \& Lee, S.H. (2015). A CIT investigation of disruptive student behaviours: the students' perspective. Marketing Education Review, 25(2), 115-126.

Ibrahim, M. \& Abdallahamed, S. (2014). Service recovery and customer satisfaction: A case of Ugandan Telecom. European Journal of Business and Management, 6(4), 197-209.

Ishaque, A., Tufail, M. \& Habib, M.N. (2016). Causes of Service Failure: A Literature Review. Available online:https://www.researchgate.net/profile/Muhammad_Habib12/publication/30509450_CAUSES_OF_SERVICE_FAIL URE_A_LITERATURE_REVIEW/links/574c4308aee45b844474dc.pdf. (Accessed: 7 September 2018).

Khanmohammadi, M., Zohoori, M., Asgharian, R., Golmohammadi, K. \& Aghapour, A.H. (2014). Moderating role of the perceived justice in the relationship of trust, management support, individual attitude, and reward system with universities' lecturers' knowledge sharing. Interdisciplinary Journal of Contemporary Research in Business, 6(3), 132-158.

Kloviene, D. \& Pazeraite, A. (2017). Building a conceptual model of complaint management: theoretical insights. International Journal on Global Business Management \& Research, 6(1), 1-13.

Leow, S.C. (2015). Airline service failure and recovery. A conceptual and empirical analysis. University of Salford.

Lervik-Olsen, L., Andreassen, T.W. \& Streukens, S. (2016). What drives the intention to complain? Journal of Service Theory and Practice, 26(4), 406-429.

MacLeish, M. A. (2015). Customer Complaint Management Systems (CCMS) in a food processing industry. Senior Honours Projects. Available online: https://commons.lib.jmu.edu/honors201019/26. (Accessed: 14 April, 2021).

Michel, S. (2001). Analyzing service failures and recoveries: a process approach. International Journal of Service Industry Management, 12(1), 20-33.

Merlo, O., Eisingerich, A., Auh, S. \& Levstek, J. (2018). The benefits and implementation of performance transparency: The why and how of letting your customers 'see through your business. Business Horizons, 61(1), 73-84.

Ncokazi, Z. (2020). Deputy higher education minister fields complaints about tertiary institutions. Available online: https://www.timeslive.co.za/politics/2020-08-05deputy-higher-education-minister-fields-complaints-about-tertiaryinstitutions/. (Accessed: 13 April 2020)

Okyere, I.O \& Kumadey, G. (2015). An assessment of service failures and customer complaints management in the delivery of health care in the municipal hospitals in Ghana. International Journal of Business and Marketing Management, 3(1), 31-42

Quy, V.T \& Lan, P.T.B. (2015). The Impact of bank responses to recovery service satisfaction. Asian Economic and Financial Review, 5(9),1076-1090.

Price Waterhouse Coopers. (2014). Perspectives in higher education. Available online http://www.google.co.za/?gfe_rd=cr\&ei=X1QdVsC4C12p8we7k7v4Ag\#q=persectives+in+higher+education+pwc. (Accessed: 9 September 2018).

Ramphal, R. (2016). A complaints handling system for the hospitality industry. African Journal of Hospitality, Tourism and Leisure, 5(2), 1-15. 
Rust, R.T., Subramanian, B. \& Wells, M. (1992). Making complaints a management tool. Marketing Management, 1(3), 41-45. Scriabina, N. \& Fomichov, S. (2007). Six ways to benefit from customer complaints. American Society for Quality, Vancouver 408.

Sekaran, U. \& Bougie, R. (2016). Research methods for business: A skill building approach. $7^{\text {th }}$ ed. Hoboken, N.J: John Wiley \& Sons Limited.

Soares, R.R., Zhang, T.T., Proença, J.F. \& Kandampully, J. (2017). Why are Generation Y consumers the most likely to complain and repurchase? Journal of Service Management, 28(3), 520-540.

Stone, M. (2011). Literature review on complaints management. Journal of Database Marketing and Customer Strategy Management, 18(2), 108-122.

Tan, A.L., Hussain, K. \& Murali, S. (2014). Antecedents affecting employee service recovery performance in five-star hotel. Australian Academy of Business and Social Sciences, 1, 1-17

Tax, S.S. \& Brown, S.W. (1998). Recovering and learning from service failure. MIT Sloan Management Review, $40(1), 75$.

Timm, P.R. (2011). Customer service: Career success through customer loyalty. $5^{\text {th }}$ ed. New Jersey: Pearson.

Tjønneland, E.N. (2017). Crisis at South Africa's universities - what are the implications for future cooperation with Norway?. Available online: https://www.cmi.no/publications/6180-crisis-at-south-africas-universities-what-are the. Accessed: 13 April, 2021

Torres, E.N., van Niekerk, M. \& Orlowski, M., (2017). Customer and employee incivility and its causal effects in the hospitality industry. Journal of Hospitality Marketing \& Management, 26(1), 48-66.

Villi, B. \& Koc, E. (2018). Employee Attractiveness and Customers' Service Failure Perceptions. Journal of Hospitality Marketing \& Management, 27(1), 41-60.

Waqas. M., Khan, M.A. \& Ali, H. (2014). An investigation of effects of justice recovery dimensions on students satisfaction with service recovery in higher education environment. Int Rev Public Non-Profit Mark, 11, 263-284.

Wilson, A., Zeithaml, V.A., Bitner, M.J. \& Gremler, D.D. (2012). Services marketing: Integrating customer focus across the firm. Berkshire: McGraw Hill.

Publisher's Note: SSBFNET stays neutral with regard to jurisdictional claims in published maps and institutional affiliations.

\section{(c) (1)}

(C) 2021 by the authors. Licensee SSBFNET, Istanbul, Turkey. This article is an open access article distributed under the terms and conditions of the Creative Commons Attribution (CC BY) license (http://creativecommons.org/licenses/by/4.0/).

International Journal of Research in Business and Social Science (2147-4478) by SSBFNET is licensed under a Creative Commons Attribution 4.0 International License. 